УДК $78.03+786.2$

\title{
Н. Заяи, \\ СПЕЦИФИКА ПРОЯВЛЕНИЯ ПРИНЦИПА ПРОГРАММНОСТИ В ФОРТЕПИАННЫХ ЦИКЛАХ Э. ГРАНАДОСА И М. МУСОРГСКОГО
}

\begin{abstract}
Статья посвящена анализу специфики проявления принципа программности в фортепианном цикле «Гойески» Э. Гранадоса и в «Картинках с выставки» М. Мусоргского. Названные произведения возникли на пересечении музыкальной и художественной традици (Ф. Гойя, В. Гартман) и рассматриваются в контексте жканрово-стилевых исканий русской и испанской культуры второй половины ХІХ - начала ХХ веков.

Ключевые слова: программность, «Гойески» Э. Гранадоса, «Картинки с выставки» М. Мусоргского, Ф. Гойя, В. Гартман, романтизм, Ренсимьенто.
\end{abstract}

Размышляя о специфике музыки в ряду иных видов художественной деятельности, Г. Гегель в свое время отмечал, что она более всех искусств отдалена от вещественного материального мира, поскольку «чувство слуха более идеально, чем чувство зрения и потому, что, слушая музыку, мы не имеем созерцаемого предмета, а как бы следим за движениями самой души» [4, с. 473]. Тезис о музыке как выражении невыразимого показателен для философско-эстетических позиций художественной элиты различных эпох европейской культуры и, прежде всего, ХІХ-XX ст. Так, по мнению Ш. Мюнша, «владения музыки - это не поддающаяся контролю разума и осязания сфера подсознательного». Продолжением его мысли можно считать слова Г. Нейгауза, считавшего, что «все «нерастворимое», несказуемое, неизобразимое, что постоянно живет в душе человека... и есть царство музыки. Здесь ее истоки» (цит. по: [6, с. 7-8]).

Обозначенные качества музыки свидетельствуют, с одной стороны, об удаленности ее как одного из наиболее абстрактных искусств от предметно-понятийной конкретики в художественном выражении, с другой - об обладании определенными преимуществами в передаче эмоционального состояния и настроения. Сказанное во многом обуславливает факт существования феномена программной музыки, порожденной «противоречием между извечным «стремлением» музыки избежать однозначной понятийности и столь же неуклонным «стремлением» к постоянному расширению границ в интонационном постижении бытия...» [18, с. 8-9].

(C) Заяц Н., 2016 
Программность во всем разнообразии ее проявлений в музыкально-исторической традиции давно стала предметом научных изысканий в музыкознании, о чем свидетельствуют работы В. П. Бобровского, М. Е. Тараканова, Ю. Н. Хохлова, О. В. Соколова, И. Я. Рыжкина, Г. В. Крауклиса, А. Е. Сысоевой, Л. А. Кияновской и др. Прослеживая историю данного понятия и особенности его функционирования в творчестве композиторов различных эпох, большинство из них солидарны в том, что «программной следует считать инструментальную музыку, которая имеет предпосланное авторское слово, несущее восполняюще-конкретизируюшую функцию», ориентированную либо на зрительные образы, либо на литературно-словесные [17, с. 88]. Толкование «программы» как своеобразного авторского предуведомления к инструментальному сочинению согласуется и с этимологией данного слова, поскольку программа предваряет саму музыку (pro «впереди», «перед», grafo - «пишу») (см. более подробно об этом: [13]). «Программа, - писал Ф. Лист, - ...изложенное общедоступным языком предисловие к чисто инструментальной музыке, с помощью которого композитор стремится предохранить своих слушателей от произвольного поэтического истолкования и наперед указать поэтическую идею целого, навести на ее главнейшие моменты...» [11, с. 285-286]. При подобном подходе программа в произведении, рожденном на пересечении семантики музыки, слова, зрительных образов, дает возможность распознать знаковый «код» сочинения и глубже проникнуть в его содержание, о чем в свое время писал В. Каратыгин: «Слова [в программном произведении]... бросают какой-то своеобразный рефлекс на музыку, музыка в свою очередь как-то усиливает обаяние текста, сколь бы ни был он прекрасен сам по себе. В итоге свободных взаимовлияний музыки на текст и обратно возникает множество трудно определимых... психологических обертонов, значительно раздвигающих рамки художественного восприятия...» [7, с. 161].

Наиболее ярким периодом расцвета данной музыки принято считать XIX век, ознаменовавшийся появлением не только выдающихся программных инструментальных сочинений, но и обострением музыкально-эстетической полемики по поводу «абсолютной музыки» и ее программного антипода. Столь пристальный интерес к последней во многом обусловлен ориентацией романтизма на идею синтеза искусств, предельного расширения возможностей каждой из сфер художественного выражения. В итоге, по словам Б. Асафье- 
ва, «сущность программной музыки сводится к музыкальному (т. е. средствами музыки содеянному) претворению идей поэтических, живописных и религиозно-философских в некое музыкальное Бытие. Иначе говоря, музыкант, оставаясь музыкантом, может быть и философом, и поэтом, и живописцем...» (цит. по: [10, с. 77]). В данном случае контактность и взаимодействие музыки, литературы, изобразительного искусства, запечатленная в авторской программе и в принципе программности, нацеленном на художественный синтез, становится существенным фактором в процессах не только стилеобразования, но и претворения национально-эстетических и духовных архетипов.

В этом плане весьма показателен фортепианный цикл Э. Гранадоса «Гойески», а также его аналог в творчестве М. Мусоргского «Картинки с выставки». В роли творческого импульса при создании названных сочинений выступили художественные произведения известных национальных авторов - Ф. Гойи и В. Гартмана. Названные циклы, весьма популярные в исполнительской практике, в настоящий момент переживают свой исследовательский «ренессанс». Сказанное соотносимо, прежде всего, с творчеством Э. Гранадоса, ставшим объектом внимания в музыковедении лишь в последнее десятилетие [9]. Феномен же творчества М. Мусоргского и по нынешний день создает «особое поле исследовательского притяжения», что в целом обусловливает актуальность темы представленной статьи. Ее предмет ориентирован на выявление специфики программности фортепианных циклов названных композиторов в русле духовноэстетических, национальных и жанрово-стилевых исканий русской и испанской культур середины XIX - начала XX ст.

Выбор названных сочинений достаточно закономерен и обусловлен многочисленными параллелями русской и испанской культуры, их взаимовлиянием, что наиболее очевидно проявилось в XIX ст. Широко известен глубочайший интерес русских авторов к испанской художественной культуре и музыке, начиная с деятельности М. И. Глинки. В свою очередь русская музыкальная культура стала одним из стимулов творческих новаций эпохи Ренасимьенто, одним из ярких представителей которой является Э. Гранадос. Одновременно, при всех различиях и самобытности, Россия и Испания относятся к типу так называемых «пограничных культур», для которых характерно «постоянное напряжение между двумя полярными тенденциями: охранительной и космополитической, «всемирной отзыв- 
чивостью» и сохранением традиций, сочетание которых и является не только естественным, но и единственно возможным для подобного типа культур, динамичным фактором их развития» [1, с. 60-61]. Данные качества нашли запечатление и в обозначенных выше циклах Э. Гранадоса и М. Мусоргского.

«Гойески» Э. Гранадоса, известные в фортепианном и сценическом вариантах (в виде одноименной оперы), были созданы в 1909-1914 гг. под непосредственным воздействием художественных работ Ф. Гойи, посвященных образам махи и махо, концентрировавших в себе наиболее характерные качества испанского менталитета. Отметим также достаточно своеобразный характер взаимосвязи цикла Э. Гранадоса (равно как и его сценической версии) с работами Ф. Гойи. С одной стороны, очевидна конкретика апеллирования композитора к живописным первоисточникам, обнаруживаемая в подчеркнутом интересе к наследию художника, к тематике его творчества, в копировании его некоторых работ, сопряженных с образно-смысловыми приоритетами цикла. С другой стороны, «Гойески» Э. Гранадоса нельзя считать музыкальной иллюстрацией работ Ф. Гойи. Последние скорее стали для композитора источником вдохновения, пробуждения духовно-творческой фантазии в претворении национальной тематики и характерных испанских типажей махи и махо, равно как и сама творческая фигура Ф. Гойи. «Первое, что предстает перед взором при входе в музей Прадо в Мадриде, - писал в одном из своих писем Э. Гранадос, - его [Гойи] статуя, облик которой призван способствовать величию нашей родины... Меня вдохновляет человек, так прекрасно и точно воплотивший в своих произведениях испанский национальный характер» (цит. по: [9, с. 62]).

Сказанное в полной мере подтверждает «вписанность» данного сочинения в национальную испанскую музыкальную традицию рубежа XIX-XX ст., развивавшуюся под знаком искусства Ренасимьенто, а обобщенно представленная в ней драма любви и ревности махи и махо, равно как и ее герои, носит не только конкретно индивидуальный характер, но и приобретает смысл обобщения жизненного пути человека с выделением в нем наиболее важных (с позиций испанской ментальности и национальной идеи) аспектов - любовь («Влюбленные щеголи», «Беседа у оконной решетки»), страсть, ревность («Маха и соловей»), смерть («Любовь и смерть»), взаимопроникновение реального и мистического («Призрак, поющий серенаду»), оппозиции жизни и смерти, их одухотворенность, что в конечном итоге и со- 
ставляет смысл такого существенного понятия испанской духовной жизни как дуэнде.

Э. Гранадос в своем произведении в интерпретации национального качества исходит не из географии (как, например, его современник И. Альбенис), но опирается на творчество Ф. Гойи как на символ, знак художественного запечатления собственно испанского качества. Композитор также акцентирует внимание на внутренней душевной жизни испанца, представленной через характерные типажи, из которых, как указывалось выше, предпочтение отдавалось махо и махе. Вместе с тем, очевидна и опора на испанскую песенно-танцевальную и фольклорную традицию фламенко (вплоть до цитат в пьесах «Влюбленные щеголи», «Фанданго при свечах»), на показательный для него «андалузский лад» на гитарное исполнительское искусство Испании с характерными оригинальными приемами звукоизвлечения.

Таким образом, в цикле реализуется родовое для испанской культуры и столь показательное собственно для романтизма тяготение к синтезу искусств, к органичному взаимопроникновению национальной живописи, танца, пения (появление «Гойесок» предваряет вокальный цикл «Тонадильи», ставший интонационной основой многих номеров фортепианного цикла), гитарного исполнительства. Каждая из выделенных составляющих данного синтеза, помимо авторских определений, также выполняет роль своеобразной программы, то есть тех «психологических обертонов», которые, согласно В. Каратыгину, существенно углубляют смысл главных образов «Гойесок» и позволяют воспринимать их на уровне музыкального запечатления испанской национальной идеи.

Столь многообразная жанровая основа также во многом определяет неординарность типологических качеств самого цикла Э. Гранадоса в целом. Как отмечает К. Розеншильд в своей монографии «Энрике Гранадос», «Гойески» часто называют сюитой для фортепиано, но это название неточно обозначает циклическую структуру и образный строй произведения. «Каждая из пьес - это своеобразная испанская рапсодия или концертная фантазия на испанские темы. Тип последовательности, порядок, в каком пьесы чередуются друг с другом, тоже не сюитен. Композитор то придерживается принципа смежности контрастных частей, то от него отходит. Сюита означает последование малых форм, а отдельные «гойески» слишком широкомасштабны. Пьесы написаны в свободной форме, что позволяет соотнести их с жанром каприччио» [14, с. 37-38]. 
Одновременно данный цикл, при всем доминировании в нем «испанского качества», имеет контакты и с европейской музыкальной традицией, что очевидно в тяготении Э. Гранадоса к цикличности, рапсодичности, а также к стилевым и фактурным качествам творчества Ф. Листа, Ф. Шопена, Р. Шумана.

Широта, всеохватность творчества М. Мусоргского, его жанровостилевые открытия, получившие достойную оценку лишь в ХХ ст., и ныне предоставляют необычайный интерес для современного исследователя, порождая мощные «эвристические импульсы». По мнению Г. В. Свиридова, «творчество Мусоргского бесконечно глубоко и разнообразно. В нем причудливо сцеплены сложные вопросы национального бытия, кипят, бушуют могучие социальные страсти, борются крупные и разнообразные характеры, богатство народного быта, бесконечное разнообразие чувств. Но доминирующей идеей является религиозная идея, вера - как идея жизни, тайный смысл существования нации» [16, с. 457]. Характерно, что столь грандиозную задачу композитор решает (подобно Э. Гранадосу, только на почве русской культуры), опираясь на контактность и взаимопроникновение литературы, безусловно доминировавшей в русской культуре XIX в., изобразительного искусства и собственно музыки. Отметим также, что подобный синтез в творчестве М. Мусоргского, неоднократно отмечаемый его современниками, был одним из знаков «новых берегов», стремление к которым стало творческим кредо композитора. Согласно наблюдениям Е. Ручьевской, исследующей вопросы соотношения слова и внесловесного содержания в творчестве М. Мусоргского, музыка в эстетических представлениях данного автора «...не выходит за пределы свои (здесь очень важен принцип художества, художественного, который он отстаивал), но расширяет свою территорию, поле музыки захватывает новые пласты жизни - те, что подлежат «захвату», находятся в рамках ее художественной специфики» [15, с. 200-201].

Сказанное очевидно не только в музыкально-театральных и камерно-вокальных композиций М. Мусоргского, но и в его фортепианном цикле «Картинки с выставки», который и поныне считается шедевром мировой фортепианной классики и, одновременно, одним из самых загадочных творений композитора, в рамках которого парадоксальным образом сосуществуют «философичность концепции и всепроникающий юмор, почти натуралистическая достоверность и захватывающая фантастика, нездешняя таинственность и элементы злободневной социальной сатиры» [3, с. 138]. 
Подобная образная и смысловая всеохватность - «на земле, в небесах и в преисподней» (по образному определению В. Вальковой) во многом определяет многозначность жанрового обозначения данного произведения, именуемого (как и «Гойески Э. Гранадоса») и сюитой, и циклом. Генезис «Картинок с выставки» также нередко возводят к карнавальной культуре и ее романтическому «аналогу» шумановскому «Карнавалу». Наконец, В. Валькова связывает семантику образной концепции данного произведения с жанром античной мениппеи.

Вместе с тем, при всем образном богатстве этого сочинения, в программных заголовках которого автор использует шесть языков (французский, итальянский, польский, идиш, латынь, русский), ориентации на разнообразные культурно-исторические традиции, очевиден, прежде всего, национальный русский колорит этого фортепианного цикла, идея и замысел которого во многом определены связью с творчеством В. Гартмана, которое стало своеобразным (как и в случае с Э. Гранадосом) творческим импульсом для композитора.

Уникальная личность В. Гартмана, сочетавшего таланты художника, декоратора, архитектора, прочно связана с формированием и сложением в России в середине XIX ст. «русского стиля», базировавшегося на идее возрождения форм и приемов древнерусского (допетровского) зодчества и декоративно-прикладного искусства. Теоретиками данного стиля стали историк И. Е. Забелин, а также критик и идеолог «кучкистов» В. В. Стасов. Согласно концепции «русского стиля», «национальное или общенародное ассоциировалось с высшими жанрами древнерусского искусства, прежде всего с храмами, росписями, иконописью», исток которых возводился к традициями византийской культуры [12, с. 47]. Богатое в образно-смысловом, жанровом и стилевом плане творчество В. Гартмана в полной мере вписывалось в данную художественную концепцию и потому так импонировало М. Мусоргскому, видевшему в нем своего единомышленника. «В художественных принципах Гартмана Мусоргский видел родство с собственными поисками национальной самобытности русской музыки. В финале [«Картинок с выставки»] он воздвиг духовный храм, построенный на этих этических и эстетических постулатах, общих для него и Гартмана. Цель Мусоргского - драматургическое столкновение фундаментальных этико-философских пластов, один из которых символизирует в человеческой жизни бренное, сиюминутное, суетное, а другой - обретение божественной истины и кра- 
соты» [2, с. 107]. Закономерным в связи с вышесказанным видится цитирование М. Мусоргским в «Богатырских воротах» как кульминационной пьесе цикла народной песни «Ярослав-город» (первая тема) [19, с. 190-191] и обиходного напева «Елицы во Христа крестистеся» (вторая тема) [5, с. 204] с соответствующей ладово-интонационной организацией.

«Дух» творчества В. Гартмана ощутим не только в названиях пьес и авторских ремарках на полях «Катакомб», но и в первоначальном наименовании цикла «Виктор Гартман» [3, с. 141]. Вместе с тем сопоставление музыки М. Мусоргского с художественными прообразами В. Гартмана свидетельствует о самостоятельности их творческой интерпретации композитором. «Картинки с выставки», по меткому наблюдению В. Вальковой, - «это... напряженный творческий диалог двух художественных миров, объединенных склонностью к странствиям и поискам высшей истины и красоты. Гартман, «...совершавший все с крылатостью пылкой фантазии», вызвал ответную реакцию у пылкой фантазии Мусоргского» [3, с. 141].

Итак, обзор жанрово-стилевой и образно-смысловой специфики «Гойесок» Э. Гранадоса и «Картинок с выставки» М. Мусоргского, отразившихся на их качествах как образцов программной музыки, при всем их национальном своеобразии, обнаруживает массу точек соприкосновения. Оба композитора апеллируют к наследию известных художников, творчество которых стало своеобразным символом национальной культуры Испании и России XIX ст. В большей степени это соотносимо с творческой фигурой Ф. Гойи, в то время как В. Гартман был одним из видных репрезентантов «русского стиля», существенного для «кучкистов» и М. Мусоргского. Одновременно деятельность названных авторов можно рассматривать на уровне творческого импульса для композиторов, создавших вполне самостоятельные творческие концепции в своих фортепианных циклах, в рамках которых живописный и музыкальный планы взаимно дополняют друг друга («восполняюще-конкретизирующая функция программы» по О. Соколову). Из богатого художественного наследия Ф. Гойи Э. Гранадос отдает предпочтение фигурам махи и махо. Избирательный подход в отборе образно-живописных первоисточников В. Гартмана характеризует и замысел М. Мусоргского. При этом творческий диалог музыкального и живописного начал в анализируемых циклах позволяет говорить о воплощении в них моделей национального образа мира, национальной идеи, духа 
нации. Для Э. Гранадоса олицетворением данного качества становится символически обобщенное воплощение драмы махи и махо, балансирующей на грани реального и потустороннего, праздника жизни, любви и ее трагико-мистического финала в духе дуэндо. У М. Мусоргского утверждение величия национальной идеи в финальной пьесе цикла становится итогом странничества «на земле, в небесах и в преисподней».

Подобного рода программность, запечатлевающая образно-смысловое богатство «психологических обертонов» анализированных сочинений Э. Гранадоса и М. Мусоргского, обусловливает их жанровую «открытость», позволяющую трансформировать фортепианный цикл либо в оперу («Гойески»), либо в оркестровую сюиту («Картинки с выставки» в оркестровке М. Равеля). Подобного рода жанровые модификации во многом обусловлены показательной для обоих сочинений универсальностью фактуры и темброво-интонационных решений, в соответствии с которой фортепиано трактуется не только с позиций потенциального воплощения оркестрового качества, но и на уровне «озвучивания» национальной тембральности. Для Э. Гранадоса - это воспроизведение гитарно-певческо-танцевального комплекса фламенко, в то время как для М. Мусоргского существенным оказывается запечатление симбиоза фольклорной, церковнопевческой и колокольной традиции как звуковых символов-«кодов» русской культуры.

Отметим также, что обозначенные качества в анализируемых фортепианных циклах неотделимы от широкого спектра жанровых обобщений, в рамках которых ярко выраженный национальный элемент (испанский и русский) дополняется творческим усвоением авторами совокупного опыта европейской музыкально-исторической традиции. В подобном случае, согласно выводам Г. В. Крауклиса, «одним из действенных приемов программной конкретизации музыки является [также] жанровая характерность музыкальных образов» поскольку «...в жанре воплощается типизированное содержание» (В. А. Цуккерман) [10, с. 32-33]. Для «Гойесок» Э. Гранадоса в этой роли выступают семантико-типологические качества культуры фламенко, в то время как «Картинки с выставки» М. Мусоргского демонстрируют высочайший уровень жанровых обобщений русской музыкальной культуры второй половины XIX ст., предвосхищающих одновременно творческие открытия XX в. в постижении и запечатлении глубин человеческого духа как одного из важнейших качеств не только русской 
музыки, но и музыкального искусства в целом. Обобщением сказанного могут служить слова К. Леви-Стросса: «Если музыка - язык для создания сообщений, по крайней мере, часть из которых понятна подавляющему большинству, хотя лишь ничтожное меньшинство способно их творить; и если среди всех остальных языков только этот язык объединяет в себе противоречивые свойства быть одновременно умопостигаемым и непереводимым, - то это само по себе превращает создателя музыки в существо, подобное богам, а саму музыку в высшую тайну науки о человеке [8, с. 162].

\section{СПИСОК ЛИТЕРАТУРЫ}

1. Астахова Е. В. Испания как метафора (К перекрестному году России в Испании и Испании в России) / Е. В. Астахова // Вестник МГИМО университета. - 2011. - № 6. - С. 60-65.

2. Берченко Р. Композиторская режиссура М. П. Мусоргского / Р. Берченко. - М.: Едиториал УРСС, 2003. - 224 с.

3. Валькова В. На земле, в небесах и в преисподней. Музыкальные странствия в «Картинках с выставки» / В. Валькова // Музыкальная академия. 1999. — № 2. - C. 138-144.

4. Гегель Г. В. Ф. Эстетика: в 4 томах / Г. В. Ф. Гегель. - М.: Искусство, 1971. - Т. 3. $-623 \mathrm{c}$.

5. Головинский Г. Мусоргский и древнерусская певческая традиция /

Г. Головинский, А. Конотоп // Музыкальная академия. - 1993. - № 1. C. $203-206$.

6. Казанцева Л. П. Основы теории музыкального содержания: учебное пособие / Л. П. Казанцева. - Астрахань: ИПЦ «Факел» ; ООО «Астраханьгазпром», 2001. - 368 c.

7. Каратыгин В. Музыка чистая, программная, прикладная / Каратыгин В. Избранные статьи. - Л.: Музыка, 1965. - С. 155-163.

8. Коженкова А. С. Знаковая природа музыки / А. С. Коженкова // Молодой ученый. - 2012. - № 1, т. 2. - С. 159-162.

9. Красотина И. В. Энрике Гранадос. Фортепианное наследие : дис. ... канд. искусствоведения : 17.00.02 - Музыкальное искусство / И. В. Красотина. - М., 2010. - 192 с.

10. Крауклис Г. В. Романтический программный симфонизм. Проблемы. Художественные движения. Влияние на музыку ХХ века / Г. В. Крауклис. М.: МГК им. П. И. Чайковского, 2007. - 312 с.

11. Лист Ф. Избранные статьи / Ф. Лист ; пер. Н. Мамун, А. Бобович. М.: Музгиз, 1959. - $463 \mathrm{c.}$

12. Орлова Е. Ю. Формирование и развитие теории «русского стиля» в архитектуре и искусстве (XVIII - начало XX вв.) / Е. Ю. Орлова // Мир науки, культуры, образования. - 2009. - № 3 (15). - С. 45-48. 
13. Программа [Интернет-ресурс]. - Режим доступа : https://ru.wiktionary. org/wiki/программа

14. Розеншильд К. К. Энрике Гранадос / К. К. Розеншильд. - М.: Музыка, 1971. $-87 \mathrm{c}$.

15. Ручьевская Е. Слово и внесловесное содержание в творчестве Мусоргского / Е. Ручьевская // Музыкальная академия. - 1993. - № 1. - С. 200203.

16. Свиридов Г. В. Музыка как судьба / Г. В. Свиридов. - М.: Молодая гвардия, 2002. -779 с.

17. Соколов О. В. Морфологическая система музыки и ее художественные жанры : монография / О. В. Соколов. - Нижний Новгород: Издательство Нижегородского университета, 1994. - 220 с.

18. Сысоева А. Е. Программность в инструментальной музыке эпохи барокко: проблемы типологии национальных школ : автореф. дис. ... кандидата искусствоведения : 17.00.02 - Музыкальное искусство / А. Е. Сысоева. - М., 1993. - $22 \mathrm{c}$.

19. Трембовельский Е. Модальное развитие - одна из основ мышления Мусоргского / Е. Трембовельский // Музыкальная академия. - 1993. № 1. - C. 187-192.

Заєць Н. Специфіка прояву принципа програмності у фортепіанних циклах E. Гранадоса i M. Myсоргського. Стаття присвячена аналізу специфіки прояву принципа програмності у фортепіанному циклі «Гойєски» Е. Гранадоса та в «Картинках з виставки» М. Мусоргського. Названі твори виникли на перетині музичної та художньої традиції (Ф. Гойя, В. Гартман) та розглядаються в контексті жанрово-стильових пошуків російської та іспанської культури другої половини XIX - початку XX століть.

Кл ючові слова: програмність, «Гойєски» Е. Гранадоса, «Картинки з виставки» М. Мусоргського, Ф. Гойя, В. Гартман, романтизм, Ренасімьєнто.

Zayaz N. Manifestation of the principle of specificity of software in the piano cycle E. Granados and M. Mussorgsky. This article analyzes the specific features of manifestation of the principle of software in a piano cycle «Goyescas» by E. Granados and «Pictures at an Exhibition» by Mussorgsky. Said works emerged at the intersection of music and art tradition (F. Goya, V. Hartmann) and are considered in the context of genre-style searching Russian and Spanish culture in the second half of XIX - early XX centuries.

Keywords: software, «Goyescas» by E. Granados, «Pictures at an Exhibition» by Mussorgsky, F. Goya, V. Hartmann, romanticism, Renacimiento.

Стаття надійшла до редакцї 13.04.2016

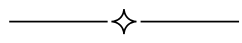

